Vesa Kyllönen

\title{
Maksimalistinen aivokartta. Metafyysinen salapoliisi- kertomus Jaakko Yli-Juonikkaan Neuromaanin tiedollisena työkaluna
}

Jaakko Yli-Juonikkaan Neuromaanin (2012) vastaanotto oli varovaisen myönteinen. Vaikka esimerkiksi Parnasson Tuomas Juntunen uskaltautui kohottamaan teoksen James Joycen Ulysseksen (1922) ja Georges Perecin Elämä käyttöohjeen (1978) rinnalle, päivälehdissä emmittiin: Helsingin Sanomain Matti Mäkelä ei olisi mielinyt kutsua sitä romaaniksi lainkaan, ja Juhani Brander (2012) katsoi Turun Sanomissa teoksen kärsivän "natriumin yliannostuksesta, jossa lukijan aivotoimintoja tasapainottavaa nestettä imeytyy liiaksi hukkaan". Erityiseksi ongelmaksi koettiin teoksen tiedollinen ylenmäräisyys. Neuromaanissa tuntui liikkuvan "valtava määrä triviahetteikköä” (Mäkelä 2012), se "kompuroi hyperbolassaan" (Brander 2012) ja käytti lähdeaineistoaan liiaksi.

Päivälehtikritiikeissä nousivat esiin samat huomiot, jotka vastaavat omaa lukukokemustani: materiaalin laajuus ja informaation liiallisuus hallitsevat Neuromaania. Tämä eksessiivisyys kytkee teoksen osaksi ensyklopedisen romaanin perinnettä, johon on liitetty esimerkiksi Richard Powersin, David Foster Wallacen ja William T. Vollmannin teoksia (ks. esim. LeClair 1996; Burn 2007, 60). Ensyklopedinen romaani viittaa etenkin sotienjälkeisessä amerikkalaisessa kirjallisuudessa tietoa koskevia lajipiirteitä toteuttavaan maksimalistiseen genreen tai modaliteettiin. ${ }^{1}$ Mutta ilmeneekö Neuromaanissa samaa kerronnallista pyrkimystä kattavaan tiedolliseen kokonaiskuvaan kuin romaanimuodon amerikkalaisissa edustajissa? Entä onko siinä muita ensyklopediselle romaanille tyypillisiä elementtejä, kuten kertomusmateriaalin liikakasvua, detaljirikkautta ja poikkeamien lukuisuutta sekä näitä rönsyjä esimerkiksi tieteen keinoin hillitsemään ja jäsentämään pyrkivä rakenne (Ercolino 2014; Karl 2001, 155-225)?² Jo Neuromaaniin liitetty sisällysluettelo viittaa tähän suuntaan: aihekirjo on valtava, mutta lukuja hallitsee aivotutkimus, tieteellinen metodologia ja niiden parodia ("Tieteellisen huippulahjakkuuden ja skitsofrenian kohtalonyhteys", "Tiedemiesidentiteetin muovautumisen kulttuuriset reunaehdot"). Myös kriminaalipsykologinen aihepiiri ("Aggressiiviset aivot", "Seksuaalirikollisen aivot") korostuu lukujen otsikoissa.

Alustavat kysymykset Neuromaanin ensyklopedisuudesta kuitenkin vasta viitoittavat tien. Miten romaanin tietomateriaali oikeastaan jäsentyy? Ensyklopedinen romaanihan ei ole vain kulttuurisen tiedon näytteilleasettelu, vaan myös kuvaus tiedollisen järjestäytymisen prosessista (Clark 1990, 17). Ensyklopedisuutta ei ole ilman tiedon 
organisoimisen motiivia. 1900-luvulla suosituimman mallin kertomuksessa toteutettavalle tietomateriaalin järjestelemiselle on tarjonnut salapoliisikertomuksen kaava. Sotien jälkeen, etenkin Jorge Luis Borgesin, Vladimir Nabokovin ja Alain RobbeGrillet'n kertomuksissa tämä kaava kuitenkin toistuvasti käännetään itseään vastaan ja ylitetään. Kaavan parodisesta hyödyntämisestä kehkeytyy niin sanottu metafyysisen salapoliisikertomuksen genre ja kaavasta itsestään väline laajempien epistemologisten ja ontologisten kysymysten avaamiseksi. (Ks. esim. Merivale \& Sweeney 1999.) Genren "metafysiikka" ilmenee siis ennen muuta rikostutkinnan laajentamisena todellisuuden kategorioita ja niiden tulkintaa koskevalle tasolle: mikään edes salapoliisikertomuksen maailmassa ei ole varmaa tai selvärajaista. Lajityyppejä viljalti hyödyntävän ensyklopedisen romaanin kannalta tämä tulkinnan monimutkaistumista ja tiedon ambivalenssia korostava genre muotoutuukin juuri parahiksi tullakseen käytetyksi uudelleen ensyklopedisissa pyrinnöissä. Ensyklopedisessa romaanissa laaja tekstimateriaali ei jäsenny kuin salapoliisikertomus, mutta siitä erottuu lajille ominaisia komponentteja (etsivä, tutkinta, rikos, kadonnut tai labyrinttimainen teksti, vihjeiden mielettömyys, häilyvät identiteetit; ks. mt., 8-11).

Neuromaanissa kaksi ensyklopedisen romaanin vastakkaista piirrejoukkoa - yhtältä rönsyily liikesuuntana ja toisaalta tiedon jäsentely eräänlaisena rikostutkintana - lyövät kättä. Myös Mäkelä löytää materiaalivarastoksi kutsumastaan Neuromaanista tämän juonteen: "selvittämätön murha” yhdistää triviaa ja lukemattomia kohtauksia (Mäkelä 2012). Tietoaineksen jäsentävänä motiivina on siis tapahtumien taustalle jäävä rikos, jonka tutkintaprosessiin lukija kysytään mukaan.

Tarkastelen tässä artikkelissa tiedon jäsentelyyn liittyvää metafyysisen salapoliisikertomuksen geneeristä rekisteriä Neuromaanissa ja pyrin osoittamaan sen käyttökelpoisuuden romaanin tiedollisena työkaluna. Tiedolliset kysymykset ovat Neuromaanissa läsnä paitsi tekstimateriaalin rönsyilevässä laajuudessa myös juonen tasolla, jolloin niihin vastaamista on lukijan vähintään harkittava. Näin pyrin vastaamaan, miksi lehtikriitikoiden tekemät havainnot ovat oikeansuuntaisia. Yli-Juonikkaan teoksen lukeminen tässä valossa nimittäin osoittaa, että jos fiktiivisten ensyklopedioiden tunnustetaan sisältävän aineksia niin esseestä, menippolaisesta satiirista kuin epiikastakin (Clark 1990, 3-13), uudempana ainesosana on pidettävä juuri metafyysistä salapoliisikertomusta. Tiedon organisointi on "informaatioajan" ensyklopedisessa romaanissa yhä merkitsevämpää, koska kokonaisuus näyttäytyy liikakasvuisena ja tiedollisesti hallitsemattomana.

Juntusen (2012) tarjoamalle romaanijoukolle voidaan täten esittää vaihtoehto: Thomas Pynchonin Painovoiman sateenkaaren (1973), Umberto Econ Foucaultin heilurin (1988) ja Mark Z. Danielewskin House of Leavesin (2001) kaltaiset metafyysisen salapoliisikertomuksen maksimalistiseen haaraan liitetyt teokset jakavat Neuromaanin 
kanssa ainakin tiedollisen ylenpalttisuuden, rikostutkinnan tai etsinnän trivialisoitumisen, vihjeiden kohtuuttomuuden sekä pelkkää salapoliisikertomuksen kaavaa laajemman yhteiskunnallisen tai filosofisen pohjavireen. ${ }^{3}$ Neuromaanikin on luettavissa ensyklopedisena romaanina, jossa rikostutkinnan juonne toimii keskeisenä apuvälineenä romaanin oman tiedollisen kokonaisuuden jäsentelyssä. Lähestymistapani on tämän johdosta kahtalainen. Erittelen ensin Neuromaanin "materiaalivarastoa" labyrinttina, joka nojaa lukijan ja kertomusmuodon väliseen vuorovaikutukseen. Tämän jälkeen siirrän huomioni lukijaan, jolle romaani varaa etsivän roolin. Aluksi on kuitenkin luotava silmäys Neuromaanin muodollisiiin ominaispiirteisiin.

\section{Labyrintin suuaukolla}

Neuromaanin rakenne on ergodinen, ja teosta voidaan lukea eri järjestyksissä (ks. Kursula 2013). Lähtökohtaisesti romaanista on kuitenkin erotettavissa kaksi samanaikaista muotoa. Nimensä mukaisesti se mallintaa aivojen rakenteita, mutta samalla aivokytkentöjen arvaamattomuus muuntaa teosta itsensä tutkimuskohteeksi. Tämän vuoksi Neuromaani jäsentyy kuin tieteellinen tutkimus. Sen englanninkielisen abstraktin mukaan "tutkimus" keskittyy fiktiivisten suomalaisten neurotieteilijöiden vuosina 1999-2000 tekemiin rikoksiin. Jo tämä tarjoaa lukijalle mahdollisuuden tulkita teos rikoskertomukseksi. Osittain samaan suuntaan lukijaa ohjaa myös seuraava ote: "Approaching the criminal mind on a neurophysiological level has been traditionally performed by observing the neural regions and pathways that mediate the emotions of anger" (Neuromaani, [7]; tästä eteenpäin N). Tutkimus painottaa siis aggressiivista käytöstä tuottavien hermoratojen ja aivoalueiden merkitystä, mutta avoimeksi jää, miten rikollisen mieli oikeastaan kytkeytyy neurologien rikoksiin.

Metafyysinen salapoliisikertomus on perinteisesti jäsentynyt omasta päätännöstään käsin (Tani 1984, 41). Kertomuksen loppu on jäänyt usein avoimeksi ja rikostutkinta rauennut selvittämättömänä, etenkin jos tutkinnan kuluessa etsimisen kohde on vaihtunut, rikos menettänyt merkityksensä tai etsivä hukannut itsensä ja toimensa mielen. Maksimalismin leimaamissa metafyysisissä salapoliisikertomuksissa päätäntöä tärkeämmäksi nousevat kuitenkin ne alueet tai radat, joihin Neuromaaninkin abstraktissa viitataan. Rikostekstuurin koostaminen luovutetaan lukijalle, jolloin "tutkiva lukeminen" yhdistettynä käsityksiin jollain tapaa ensyklopedisesta kokonaisuudesta - tiedollisesta kentästä tai kertomuksesta, joka ainakin teoriassa voi sisältää mitä vain - alkaa tuottaa uusia reittejä. Lukijalle muodostuu näin jo varhain käsitys kertomuksesta järjesteltävänä kokonaisuutena.

Joiltakin osin Neuromaanin päätännöt tosin ovat avainasemassa. Romaani palkitsee lukijansa useilla, erilaisilla lopuilla, joista osa osoittautuu umpikujiksi, osa muutoin traagisiksi. Myös oikopolut, luupit sekä erilaiset aivovyöhykkeet ("Kuhinaa aivokuo- 
rella") rajoittavat lukijan liikkeitä (esim. luvussa 101 "palaa luvun 101 alkuun", N, 281); toisaalta ne tarjoavat mahdollisuuksia assosiaatioihin, palautumisiin ja kujanjuoksuihin. Päätäntöjä hallitsevampia ovatkin ne valinnat, joiden varassa lukija etenee aivojen labyrintissa. Useimpien lukujen päätteeksi tarjotaan valintatilanne. Luvussa 194 lukijaa esimerkiksi kehotetaan valitsemaan kahdesta onnellisuuskypärästä: "Yo-lakki istuu päähän paremmin, mutta silkkipytty näyttää kunniakkaammalta. Kumman kelpuutat? Yo-lakin (59) vai tohtorihatun (98)?” (N, 543.) Lukijan valinta johdattaa hänet joko lukuun 59 tai 98 .

Tämän valossa Neuromaanilla on vielä kolmaskin muoto. Aivojen ja tieteellisen monografian ohella se jäljittelee 1970-luvulla suosituiksi tulleita pelikirjoja, joissa juuri lukijan valinnat määrittävät kertomuksen kulkua ja luonnetta. Lukijalle pelikirjamaisuus mahdollistaa edestakaisin käynnin: kun valittu reitti johtaa ennen pitkää yhteen mahdolliseen päätäntöön tai luuppiin, korostuu entisestään muodon labyrinttimaisuus ja lukijan oma liikesuunta. Lukijan täytyy itse pitää huolta siitä, missä kohtaa reitti alkaa haarautua hänen näkökulmastaan epäotolliseen suuntaan.

Jo näiltä osin Neuromaanin muoto ilmentää kahta vastakkaista liikevoimaa: aivojen hermokytkentöihin ja pelikirjamaisuuteen nojaava funktio hajauttaa romaania tiedollisena kokonaisuutena, kun taas tieteellistä tutkimusta jäljittelevän funktion voisi ajatella järjestävän romaanin tietoainesta. Funktioista ensimmäinen on voimakkaampi, korostetaanhan jo romaanin alkupuolella, ettei lineaarinen luenta tule kysymykseen:

Jos olet [- - muistinero ja hallitset laajoja kokonaisuuksia, voit jatkaa eteenpäin perinteiseen tyyliin tai pomppia luvut läpi satunnaisessa järjestyksessä, ohjeista piittaamatta. Se kuormittaa liikaa huonomuistisen perusjurpon aivoja, juoni ei pysy koossa, mutta ainahan voit yrittää. $(\mathrm{N}, 17$.

Ohjeistuksessa tiivistyy ensyklopedisen romaanin varsinainen haaste: se marssittaa esiin runsaasti henkilöhahmoja ja kertojia, liikaa juonta ja avoimia polunpäitä, jolloin muistettavia yksityiskohtia on yksinkertaisesti liikaa. Kun alan tutkimuksen pioneeri Edward Mendelson (1976) esitti Painovoiman sateenkaaren olevan lajissaan ensimmäinen kansainvälinen ensyklopedinen kertomus, oli esitykseen sisältyvä huomio informaation kasvaneesta roolista vielä tähdellisempi. Informaatiosta muodostuu paitsi Pynchonilla myös myöhemmissä ensyklopedisissa romaaneissa ihmispakoinen systeeminen voima, joka vie pohjaa ensyklopedisen tiedon ihmiskeskeiseltä ideaalilta. Entropia kalvaa ensyklopediaa filosofisena alkukertomuksena, joka kuvaa ihmisen valistuksellista kohoamista tiedon rappusilla (vrt. Kuusisto 2013, 29). Ensyklopedinen romaani tulee siis nimenomaan ensyklopediana entistä tietoisemmaksi oman projektinsa läpikotaisesta mahdottomuudesta.

Tietomateriaalin runsaus ei Neuromaanissakaan varsinaisesti sivistä lukijaa. Romaani luo yhteistyössä lukijansa kanssa illuusion tiedollisesta kokonaisuudesta mutta rik- 
koo sen saman tien muistuttamalla, ettei kokonaisuuden tarkoitus ole niinkään tulla hallituksi kuin toimia pelikenttänä. Tietovaranto kasvaa kokoa lukijan valintojen ja assosiaatioiden seurauksena, ja juuri romaanin tiedolliseen kasvuun liittyvä arvaamattomuus ilmentää ensyklopedisen muodon itsetutkiskelua. Samasta syystä Neuromaani on tulkinnallisten yhtenäisyyspyrkimysten parodinen kritiikki. Tiedollisten projektien luotaaminen parodian, tutkinnan selventymättömyyden ja epistemologisen epävarmuuden keinoin ovat myös metafyysisen salapoliisikertomuksen ydintä (Merivale \& Sweeney 1999, 4). Jo se, ettei Neuromaanin lukija välttämättä koskaan edes pääse lukemaan kaikkia romaanin osioita, korostaa samaa tiedonjäsennyksen mahdottomuutta.

Kun aivot ja romaanin pelikirjamaisuus muodostavat Neuromaanin hajauttavan funktion, eikä tieteellinen muoto riitä hillitsemään sen entropiaa, olisiko tietovarannon jäsentämiseen olemassa toimivampia geneerisiä rekistereitä, esimerkiksi metafyysisen salapoliisikertomuksen piiristä? Ennen kuin alan jäljittää tätä mahdollisuutta, on paikallaan tuoda esiin se, mitä varmuudella voidaan sanoa Neuromaanin tapahtumista, siitä juonesta, jonka lukemattomia digressioita romaanin materiaaliset varannot ovat.

Kertomusmaailma luonnostellaan romaanin kahdessa ensimmäisessä luvussa. Tutkintavanki Silvo Näre odottaa mielentilatutkimusta Turun yliopistollisessa keskussairaalassa. Esitutkintamateriaalista valtaosa on sensuroitu tussilla, eikä varsinaisesta "rikosepäilystä voi muodostaa edes summittaista käsitystä" (N, 12). Se tiedetään potilaslausuntojen perusteella, että Silvo kokee "jonkun miehen" komentelevan häntä. Silvo nimeää miehen Gereg Bryggmaniksi ja sanoo tämän puhuvan mitä sattuu, ”[e]ikä aina minulle vaan jollekin toiselle. Kaikkea sekavaa. Älyttömiä väitteitä ja kysymyksiä.” (N, 14.)

Tämän jälkeen Neuromaani siirtyy varsinaiseen uomaansa. Silvon sivupersoonahäiriö toimii johdatuksena potilaan aivoihin, joihin lukija nyt sukeltaa. Silvon ja Geregin kertojaäänet sekoittuvat toisiinsa ja alkavat vaihdella ensimmäisestä toiseen ja kolmanteen persoonaan.

Tähänastinen on kuitenkin asettanut lukijalle liudan kysymyksiä. Mihin Silvo on syyllistynyt? Keitä ovat suomalaiset aivotutkijat ja mitä tekemistä heillä on Silvon kanssa? Kuka on Gereg ja mitä tai ketä hän edustaa? Nämä kysymykset ovat lukijalle keskeinen johtolanka, sillä tämän jälkeen maailmaan Silvon ulkopuolella ei enää palata. Fiktiivisen maailman varsinaiset tapahtumat korkeintaan siivilöityvät hänen harhojensa läpi. Tähän johtolankaan tarttuen käsittelen seuraavaksi niitä kerronnallisia reittejä, joita Neuromaani lukijalleen mahdollistaa, toisin sanoen aivoja jäsenneltävänä tietovarantona. Tämän jälkeen lähestyn Neuromaania tutkivan lukemisen, toisin sanoen lukijalle varatun etsiväroolin suunnasta. Tällä valotuksella pyrin uuttamaan esiin loputkin niistä Yli-Juonikkaan romaanissa esiintyvistä piirteistä, jotka ovat tyypillisiä metafyysiselle salapoliisikertomukselle ja joilla on Neuromaanissa tiedollista kokonaisuutta vakauttava funktio. 


\section{Lukija risteyksessä}

Ensyklopedinen romaani ei niinkään käytä romaanimuotoa datan varastoimiseen vaan tutkii niitä vaikutuksia, joita kasvavalla informaatiomäärällä on henkilöhahmoihin (vrt. Burn 2007, 60). Jos ajatusta jatkaa, salapoliisikertomuksen näkökulmastakaan ensyklopedisessa romaanissa keskeistä ei ole rikoksen selvittäminen vaan sen mahdolliseksi tai mahdottomaksi tekevä tiedollinen pohja. Samasta syystä Silvoa ja aivotutkijoita koskevat rikostutkinnat ovat lähinnä astinlauta muille tutkimuksille. Lukijan huomio kiinnittyy kertomuksen tietomateriaalin laajuuteen ja sen juonellisiin poimuihin. Näin hän tulee nostaneeksi kertomuksen varsinaiseksi määrittäjäksi romaanin hyödyntämistä malleista ilmeisimmän, nimittäin aivot. Jos Neuromaani näet jostakin kertoo, se kertoo aivoista: kuinka aivot toimivat, kuinka data liikkuu ja jäsentyy. Juuri aivot muodostavat paitsi puitteen myös tiedollisen mallin rikostutkinnalle.

Tutkinta ei kuitenkaan kohdistu niinkään rikollisen mieleen kuin ympäröiviin olosuhteisiin. Geregin Silvolle sanelemat käskyt kytkevät Neuromaanin kertomusaihioita toisiinsa ja lähettävät lukijan matkaan, mutta vastavuoroisesti rikostutkinnan optio johdattaa lukijaa Silvon harhoista takaisin siihen maailmaan, jossa aivotutkijat ja Silvo ovat syyllistyneet rikoksiin. Kerronnan liikakasvu muodostaa savuverhon: koska Neuromaani on kertomus miehestä, joka kuulee ääniä, ja lukijasta joka seuraa tätä tämän harhoissa, menettely sulkee meiltä kertomuksen todellisuuden. Jää arveltavaksi, mitä Silvon ympärillä oikeasti tapahtuu.

Ja arveluille annetaan syytä. Geregin puhe on paitsi käskytystä myös vihjailua. Vihjataan, että aivotutkijat Paavo Riekkinen Señor ja Urpo K. Rinne ovat saaneet aiemmin tuomiot tutkimusrahoituksen kavaltamisesta. ${ }^{4}$ Närettä taas syytetään nimeämättömästä rikoksesta, ehkä päällekarkauksesta tai taposta. Rikosvihjailut kannustavatkin lukijaa etsimään lisää vihjeitä. Onko rikoksilla jokin keskinäinen yhteys? Varmaa on, että Silvon esitutkinta-aineisto on kauttaaltaan sensuroitu; koko romaanin tasolla tiedollisella ylenmääräisyydellä on vastaava, sensuroiva tehtävä. Digressiot ovat harhautuksia itse aiheesta. Vastausten panttaaminen ja niiden evääminen lukijalta kokonaan taas on kiinteä osa metafyysistä salapoliisikertomusta.

Tutkinnan käytäntö on siis selvästi lukijan kontolla. Hänellä on käsissään kartta, joka on samanaikaisesti maasto. Kartoilla taas on yleisesti ottaen kahdenlaista käyttöä: yhtäältä ne, jotka eivät ole kartan kuvailemalla alueella, saavat karttaa lukemalla käsityksen alueesta; toisaalta ne, jotka ovat alueella, pysyvät kartalla. Neuromaanin kohdalla lukijalta vaaditaan molempia: yhtäältä olemme kartalla aivoissa, mutta toisaalta pyrimme näkemään romaanin maailman kokonaisuudessaan, siis myös sen, mitä jää Silvon aivoitusten ulkopuolelle.

Kahdessa paikassa yhtä aikaa oleminen on kerronnallisena keinona osa salapoliisikertomuksen metafyysistä kaavaa, niin erottamattomasti kaavassa on kyse lukijan 
ja etsivän keskinäisestä korrelaatiosuhteesta, ja etenkin etsivästä mallilukijana (vrt. Pyrhönen 1999, 5-7). Etsivä ja lukija ovat kuitenkin tarvinneet väliinsä tiedollisen välittäjähahmon (esim. Brownson 2014, 166). Koska välittäjä on usein paitsi etsivän apuri myös kertoja, tämä on toiminut klassisissa salapoliisikertomuksissa ennen kaikkea epistemologisena puskurina. Puskuri eristää lukijalta etsivän aivoitukset ja välittää ne käännöksinä lukijalle. Toisaalta puskuri mahdollistaa lukijan osittaisen vapauden syventyä omaan tutkimusprosessiinsa, nimittäin lukemiseen.

Kun puskurinamme toimiva Silvo osoittautuu jo ensi metreillä sivupersoonahäiriöiseksi, romaanin maailman luonne olennaisesti muuttuu. Toki Silvo itsekin muuntuu epäluotettavaksi kertojaksi, mutta merkitsevämpää on tapa, jolla Silvon ja Geregin kerronallinen paritanssi viittaa sekä kertomusaineksen latentteihin sisältöihin että ympäröiviin tapahtumiin. Esimerkiksi "myönnetään, myönnetään: tämäkin kirja sisältää pirullisia koodiviestejä, joita vain vihkiytynyt sisäpiiri ymmärtää” (N, 497) irvailee sekä piilosisältöjä etsiville että postmodernistisen romaanin vainoharhafiksaatioille, mutta on luettavissa myös toisin: yhtä lailla sanotun taustalle voi olettaa "todellisia" tapahtumia. Samalla vahvistuu oletus Silvosta aivotutkijan polvella istuvana sätkynukkena - ja komenneltavana mielenterveyspotilaanahan hän on selvästikin liian heikko puskuriksi. Näin lukijan turvallinen etäisyys mestariajattelijaan - tässä tapauksessa neurologirikollisiin - hupenee.

\section{Rikollisneroja ja sokkeloita}

Eräs modernin rikoskertomuksen tuoreemmista seuraamuksista on holmesilaisen mestaripäättelijän korvautuminen rikollisnerolla, jolla on klassinen maku ja eksentriset tavat. Neuromaanikin kuvaa tätä hahmotyyppiä, tarkastellaanhan romaanissa useita korkean aseman tieteentekijöitä, joilla on omat oudot harrastuksensa ja kyseenalaiset menetelmänsä. Edesmennyt neurologian professori Jorma Palo kirjataan esimerkiksi hahmoksi, jonka metodia Gereg hyödyntää eräässä lukujen sarjassa vain testatakseen, "tarjoaako moderni aivotutkimus uusia välineitä Suomen historian lähilukuun" (N, 386). Tämäkin romaanin reitti johtaa umpikujaan, mutta tuottaa silti temaattisen lisäjäsenen kokonaisuuteen: se tosiasia, etteivät neurotieteilijät pitäydy omassa tutkimusalassaan vaan kurottavat Bodomin murhien kaltaisiin aiheisiin, kasvaa yhdeksi romaanin johtomotiiveista. "Rikollisnerojen" aktiivisuus yhdistettynä puskurin heikkouteen tuottaa osaltaan ensyklopedisuutta.

Samassa yhtälössä lukijalle varattu etsivän rooli toimenkuvineen täydentyy - juuri lukija yhdistää pisteet ja merkityksellistää sivupolut. Roolissaan hän on velvoitettu seuraamaan reitistöä, jonka Gereg käskyillään ja vaihtoehdoillaan osoittaa. Yhtäaikainen kertomuksen sisä- ja ulkopuolella oleminen mahdollistaa kuitenkin sekä valitsemisen että palaamisen. Salapoliisikertomuksen epistemologiaan kiinteästi liittyvien labyrint- 
timallien näkökulmasta juuri palaamisen optio tekee Neuromaanista vanhanaikaisen, nojaahan se moniaalle kaoottisesti levittyvien rihmastojen tuottamisen sijaan vanhakantaiseen sokkeloonsa, jonka keskellä ei odota metaforinen Minotaurus, vaan sokkelossa kulkeminen sinänsä, sokkelo yrityksen ja erehdyksen prosessina toimii kertomuksen varsinaisena vastustajana (vrt. Eco 1986, 81).

Labyrintti Minotauruksena ilmenee lukijalle yhtäältä valinnanmahdollisuutena, toisaalta etenemisen ja palaamisen vuorotteluna. Silvon mieli "pirullisine koodiviesteineen" avustaa lukijaa "taaksepäin", kun taas Gereg johdattaa häntä syvemmälle Silvon harhoihin. Tämä kaksisuuntaisuus tulee ilmi esimerkiksi Geregin toteamassa:

labyrintti rakennettiin alunperin vankilaksi hirviölle, mutta nyk. Vankeinhoitoon käytäntö ei sovellu. Jokainen huippuälykäs aivotutkija tietää, että monimutkaisimmastakin labyrinttivankilasta pääsee pakenemaan merkitsemällä kuljettu reitti lattiaan tai seinään esim. liidulla (N, 618.)

Kysymys onkin, tietääkö lukija? Hänhän on se, joka yrittää päästä labyrintista - joko palaamalla Silvon harhoista takaisin kertomuksen maailmaan tai tavoittamalla romaanin lopun, ehkä jopa sellaisen päätännön, jossa kertomuslangat sidotaan yhteen. Pyrkiäkö siis eteen vai taakse? Mutta koska "arvaamattomuudesta kumpuaa ihmisenä olemisen perusmysteeri” (N, 598), ilmenee Neuromaanin oma labyrinttikin säännöiltään arvaamattomana pelinä. Jokainen valintatilanne on mahdollisuus syventää mysteeriä, hakeutua toisten luo, tai etääntyä kiinnostavistakin. Ei ole selvää, missä suunnassa ulospääsy oikeastaan on.

Lukujen päätteeksi tehtävien valintojen ohella Neuromaani hyödyntää David Foster Wallacen Infinite Jestin ja Mark Z. Danielewskin House of Leavesin tavoin viitteitä. Useimmat niistä ovat vain akateemista monografiamuotoa tukien viittauksia todelliseen tai keksittyyn kirjallisuuteen. Mutta alaviitteillä on myös keskeisempi, romaanin sokkeloa tukeva tehtävä. Kertoja selittää:

Silvon tapauksessa käyttöliittymä on suunniteltu niin, että alitajuntaan pääsee kurkistamaan alaviitteiden kautta, siellä halut, mielijohteet ja pelot vellovat sensuroimattomina. Herkimpiä kuulijoita neuvon ohittamaan alaviitteet - kun tiedostamattomat näyt on kerran nostettu alitajunnan pimeydestä päivänvaloon, ne eivät enää kuulu tiedostamattoman piiriin vaan muuttuvat osaksi päivätajuntaa, jolloin ne voivat alkaa hallita herkän yksilön kaikkia arkisia mielteitä ja persoonallisuuden rakenteita. $(\mathrm{N}, 87$.

Eräässä alaviitteistä neuvotaankin, että "teoksen tiedollista pohjaa ja lähestymistapoja voidaan pitää kyseenalaisina, paikoitellen jopa vääristelevinä. Turun yliopistollisessa keskussairaalassa ei todellisuudessa tehdä tutkintavankien mielentilatutkimuksia." (N, 17.) Jos tämä on sensuroimaton totuus, Näre ei makaa TYKS:ssa ja se, mitä Näreen mielen ulkopuoliseksi oletetaan, hämärtyy entisestään. 
Neuromaanin kirjallisuusviitteet voidaan kyllä lukea samoin kuin luvun aloittavat lainaukset Econ Foucaultin heilurissa, siis katsoa niiden viittaavan muihin teoksiin romaanin tiedollisen kentän rikastamiseksi. Vaihtoehtoisesti ne voidaan nähdä tahallisina harhautuksina. Viitteistä on silti muuhunkin: Neuromaanin aivokartalla ne muodostavat mutkia ja valinnan mahdollisuuksia sokkeloon siinä missä varsinaiset luvutkin. Lisäksi lukija tapaa viitteistä muita kertojia. Esimerkiksi 203. alaviitteen ”Tohtori yliosterivinokas tässä taas tyylilleen uskollisena satuilee” (N, 181) nostaa esiin sekä vieraan kommentoijan mahdollisuuden että kerronnallisen kaksoispohjan: Silvon tavoin myös Gereg saattaa olla satuilevan (kenties kirjailijaan itseensä viittaavan) tohtori yliosterivinokkaan polvella istuva nukke. Viitteillä on siten yhtäl̈ltä leipätekstiä korjaava, toisaalta kerronnan metafyysisiä rakenteita sekoittava rooli.

Yhdessä viitteet ja varsinainen kerronta muodostavat "konnotatiivisten poimujen" (N, 145) puristuman, siis aivot joita hallitsee piilevien assosiaatioiden, määräysten ja mielitekojen haarasto. Mutta koska Neuromaani on yrityksen ja erehdyksen sokkelo, haraa se loputtoman laajenevuuden ideaa vastaan: pääsyä aivojen ulkopuolelle ei ole, on vain arvailuja, kuviteltavia mysteerejä. Myös tässä mielessä romaani toimii kuin muutkin ensyklopediat: oman tiedollisen rakenteensa vuoksi se on sidottu tuottamaan vain sellaisia assosiaatioita, joilla on näkyvät siteet romaanin tietomateriaaliin. Mahdottomiin sekään ei yletä, kuten ei tiedekään, jonka kritiikiksi romaani leikkisyydessään äityy. Lähestynkin seuraavaksi Neuromaanin ensyklopedisuutta juuri sen hyödyntämän tieteellisen muodon ja "tutkivan lukemisen" näkökulmista.

\section{Tutkija ja tutkimus}

Vaikka Neuromaani järjestyy aivoina, pelikirjana ja akateemisena monografiana, viimeisen kohdalla muodolliset ehdot täyttyvät vain osittain. Abstraktin ja sisällysluettelon ohella romaani koostuu 229 luvusta numeroituine alalukuineen ja viiteapparaatteineen, mutta sisällöltään Neuromaani on tieteellisen monografian irvikuva. Tyylilliset vaihtelut kiertävät niin tieteellisiä käytäntöjä kuin hyviä tapoja. Tutkimuksen lineaarinen seuraaminenkin käy jo varhaisessa vaiheessa työlääksi eikä johdonmukaisesti kehittyvää argumenttia esiinny.

"Universumin kaikkein monimutkaisimman Koneiston" (N, 338) kartoittaminen ei tietenkään ole yksinkertainen tehtävä. Ja kun tutkimuskohteena on mielenterveyshäiriöinen ja jo monografian abstrakti osoittaa useisiin "transneurologisiin" suuntiin, nimittäin konkreettisten aivojen ulkopuoleen (eli neurologien tekemiin rikoksiin), lukijan kontolle jäävä tehtävä on lähes kohtuuton. Tehtävän haastavuuden vuoksi Neuromaani ilmoittaa omaksuvansa tieteellisenä tutkimuksena "monikerroksisen, romaanimaisen muodon" (N, [7], suom. V.K.), mikä tuo kokonaisuuteen rakenteen tuntua. Tämä on ensyklopedisen romaanin keskeinen piirre: informaatiota pursuavan 
"kaaosmoosin" vastapainoksi kertomus jäsentyy - tai yrittää jäsentyä - joidenkin kokoavien periaatteiden varaan (Ercolino 2014, 78-96). Skeemoja romaaniin kylvetään myös tietoisesti: ne ovat lukuohjeita, vääriä vihjeitä, tilallisia pisteitä, joista käsin datakaaos hetkittäin järjestyy lukijalle. Neuromaanissa tieteellisen tutkimuksen muoto ja labyrinttiviittaukset ovat vastaavia ehdotuksia skeemoiksi, mutta konkreettisia lukuohjeitakin heittyy esiin, osa vasta umpikujista palattaessa.

Tieteellinen metodi kuuluu luonnollisesti salapoliisikertomuksen peruskonventioihin. Klassisessa salapoliisikertomuksessa kuvaus rikostutkinnallisesta päättelystä on nojannut yhtäältä etsivän abduktiiviseen järjenkäyttöön ja toisaalta siihen, että lukijan ja etsivän väliin jäävä kertoja välittää lukijalle ainakin kaksi vaikutelmaa päättelyn pätevyydestä: ensinnäkin sen, että miten tahansa vihjeet järjestetään ratkaisua kohti vieviksi sarjoiksi, lukija voi luottaa, että avaintekstejä on olemassa vain rajallinen määrä. Toiseksi lukijalle on tehty selväksi, että miten tahansa sarjat muodostetaan, tutkinta vie lopulta labyrintin lävitse ja rikos saadaan selvitettyä.

Econ Ruusun nimi (1980) ja Foucaultin heiluri ovat kuitenkin esimerkkejä metafyysisistä salapoliisikertomuksista, jotka vievät pohjan näiltä ajatuksilta: onnistunut päättely on onnenkantamoinen ja semioosi rajaton. Kompleksisemmissa ensyklopedisissa romaaneissa, kuten Painovoiman sateenkaaressa, entropia taas pohjustaa toista tiedollista ongelmaa: kuinka tahansa tulkinnallisia polkuja koostetaan, jokainen valintatilanne avaa aina uusia mahdollisia tutkinnan sarjoja. Tätä tietysti myös Neuromaani kuvaa. Lisäksi ensyklopedinen muoto takaa keskenään ristiriitaistenkin ainesten lomittumisen. Niin korkeakulttuuriksi kuin puhtaasti viihteeksikin mielletty menee sulavasti limittäin fysiikan, mytologian ja historiankirjoituksen kanssa, ja kuten Hilary Clark (1990, 13) huomauttaa, kirjallisen ensyklopedian muoto on epävakaa ja jatkuvassa liikkeessä omaksuessaan piirteitä muista muodoista. Datan ylenpalttisuus vain lisää muodollista elastisuutta ja epävarmuuden tuntua. Siksi Neuromaanin lukijakin niin mielellään hakee teoksesta selittäviä kaavoja.

Salapoliisikertomuksen ennakkoehto siitä, että kertomus jäsentyy avaintekstien sarjana, onkin teoksen muodon jättämä kutsu yhteistyöhön romaanin epistemologisen mielekkyyden sommittelemiseksi (vrt. Eco 1994, 15-16). Neuromaanin lukija saa tällaisen kutsun lukuohjeiden muodossa, mutta Silvon mielenterveyshäiriöiden vuoksi vihjeiden tulkitseminen ja informaation järjesteleminen ei ole helppoa. Tietoaines ei järjesty sarjoiksi, jotka veisivät väistämättä kohti vastauksia, eikä lukija voi luottaa siihen, että tietomateriaalia olisi rajallisesti. Onnistuneita siirtoja Neuromaanissa ovat vain ne, joilla pääsee seuraavaan lukuun.

Rikostutkinnan kannalta huomionarvoista on myös se vaivannäkö, jolla romaani näiden siirtojen myötä käy näkyvästi salapoliisikertomuksen päättelyä vastaan. Esimerkiksi 65. luvussa Gereg löytää talonkulmalta tuntemattoman ruumiin. 
Otetaan kuitenkin rauhallisesti. Nyt täytyy ajatella. Tämä on murhamysteeri. Kulkemani polun varrelle on tähän mennessä ripoteltu liuta vihjeitä, jotka tarkkaavainen lukija on poiminut talteen. Niiden perusteella voidaan askel kerrallaan ja aukottomasti päätellä murhaajan henkilöllisyys. Jännitys tiivistyy: kumpi tarinan arkkikonnista on tehnyt verityön, piilottanut irtopään liiteriin nurkan taa? Neurokoreografi - siirry lukuun 61. UKR - siirry lukuun 190. $(\mathrm{N}, 192$.

Valittavista luvuista ensimmäisessä lukija sysätään keskelle perheväkivaltatilannetta, jossa Gereg tulee vaimonsa Biritin surmaamaksi. Luvussa 190 - "Tiedemaailman talousrikosten kontekstualisointi ja ristivalaistus" - tuntematon ruumis taas on tykkänään unohdettu. Sen sijasta lukijaa valaistaan, kuinka "perinteiset whodunnit-salapoliisikertomukset voivat olla hyvää viihdettä ja aivojumppaa, mutta tosielämän rikollisuuden ymmärtämiseen ne tarjoavat yleensä niukasti välineitä’ (N, 534). Luku päättyykin toruun: ”Ts. vaikka olit kieltämättä päätelmissäsi oikeilla jäljillä, sorruit loppusuoralla pintapuoliseen ajatteluun. Niinpä kehotan sinua peruuttamaan lukuun 59 ja punnitsemaan valintasi uudelleen.” (N, 537.)

Tämä toivottomuus, joka Neuromaanin umpikujissa ja luupeissa lukijalle lankeaa, ilmentää hyvin etsivätoiminnan mahdottomuutta metafyysisessä salapoliisikertomuksessa. Tätä romaani suorastaan alleviivaa osoittamalla, että lukijan valinnat ja päättely ylipäänsä eivät saattele häntä ainoastaan värille jäljille vaan myös saavat aikaan katastrofaalisia seurauksia. Valtaosa Neuromaanin lopuista päättyy näet Silvon kuolemaan tai mielenterveyshäiriöiden syvenemiseen. Selvää on, että näin Neuromaani kyseenalaistaa jatkuvasti lukemistaan, sikäli kuin lukeminen on läheistä sukua rikostutkinnalle. Vihjaillut asetelmat - murhamysteeri lähtötilanteena, pintapuolinen ajattelu hairahduksena, tosielämän rikollisuus, jota ei salapoliisikertomuksilla selitetä antavat silti lisäaihetta kysyä, millaisia Neuromaanin metafyysiset rikokset lopulta ovat.

\section{Interaktiivisia murhia ja ylin juonija}

Kun Neuromaanin painopiste on tutkivassa lukemisessa, lukuohjeita tuottuu myös lukijan ja muodon vuorovaikutuksessa. Lukeminen kohostaa kerronnan aineksista esiin järjestäviä skeemoja. Usein lukuohjeet ovat kuitenkin vääriä vihjeitä: jää lukijan tehtäväksi vertailla niitä keskenään ja valita suotuisimmat. Nämä harhautukset korostavat entisestään etsinnän motiiveja, siis niitä kerrontaa jäsentäviä kysymyksiä - mistä Neuromaanissa on lopultakin kyse? - joiden vastaukset katoavat edeltä sitä mukaa, mitä hanakammin lukija niitä tavoittelee. Samalla tavoinhan lukija näyttää alati etääntyvän Silvoa ympäröivistä tapahtumista, ”tosielämän rikollisuudesta”.

Käyttöliittymän avoimuus merkitsee pohjimmiltaan sitä, että romaania ei saa toimimaan mielivaltaisilla tavoilla, vaan ainoastaan siten kuin se toimintaperiaatteineen sallii (Eco 1994, 3). Gereg on kerronnan hallitseva ääni, selittäjä ja alustaja, mutta siinä 
missä lukijan silmissä Gereg ja Silvo sekoittuvat, interaktiivisen käyttöliittymän takia keskushenkilö Silvon "personal trainerille" (N, 17) pedatun roolin täyttää vuoroin lukija, vuoroin Gereg itse. Lukijan sinuttelu tuo kuitenkin myös lukijan yhdeksi romaanin päähenkilöistä. Hänen kannaltaan keskeistä onkin, että vaikka romaani eritteleekin aivotutkimusta, sen ydin on neurologien väärinkäytöksissä. Gereg kuvailee esimerkiksi, kuinka hypnoosissa "kohde alistuu totaaliseen ajatuskontrolliin, ja vastuuttomissa käsissä tämä tuottaa välittömän ihmisoikeudellisen uhan” (N, 339). Tämänsukuiset viittaukset leimaavat romaania yleisesti ja tuovat sitä lähemmäs esimerkiksi Painovoiman sateenkaarta. Erityisesti ne saavat lukijan ajattelemaan Silvoa. Mitä hänelle on tapahtunut? Kuka hän on? Onko Silvo aivotutkija itsekin, osa työryhmää vai neurologien ikioma golem, joka on luotu kostamaan heihin kohdistunut mustamaalauskampanja ja surmaamaan eräs romaanin taka-alalle jäävistä etsivistä, Markus Rambo? Vai onko todellinen golem sittenkin lukija?

Sen lukijan sinuttelu osoittaa varmasti, että olipa Silvon rooli romaanissa mikä hyvänsä, lukijaa järjestetään hänen kanssaan samaan ruotuun. Erään luvun alaviitteessä tämä sanotaan suoraan:

Nyt kun tarinalinja on saatu päätökseen, voidaan paljastaa Geregin olevan fiktiivinen romaanihenkilö [- - Kyseessä on muunnelma klassisesta Milgramin tottelemiskokeesta [- - Neuromaani on puolestaan pyrkinyt tutkimaan, missä määrin koehenkilöitä voidaan ohjailla esittämällä heille valinnanvapauden illuusio [- - Se, että olet lukenut teosta näin pitkälle, todistaa että aivan tavallinen ihminen voidaan manipuloida törkeisiin ihmisoikeus- ja talousrikoksiin myös luomalla asetelma, jossa hän uskoo tekevänsä itsenäisiä valintoja "tarinamme sankarin" puolesta. (N, 443.)

Toisaalla Gereg kertoo: "Tiedät hyvin, että minulla on sinuun totaalinen valta, pystyn ohjailemaan sinua mieleni mukaan [- - ]. Kuitenkaan en anna mahtiasemani sokaista itseäni, uskon yhdenvertaisuuteen, haluan keskustella, kuunnella, asettua asemaasi." (N, 381.) Näin lukeminen vertautuu yhä enemmän hypnoosiin. Rikokset siirtyvät juonen tasolta tulkinnan tasolle. Tämän näkyvämmin ei salapoliisikertomusta juuri voisi kytkeä metafysiikkaan.

\section{Lopuksi}

Olen edellä pyrkinyt osoittamaan, että metafyysistä salapoliisikertomusta voidaan hyvin syin pitää mielekkäänä, koheesiota Neuromaaniin tuovana geneerisenä rekisterinä. Jos aivopoimut ja pelikirja muodostavat Yli-Juonikkaan romaanin hajauttavan funktion, on metafyysinen salapoliisikertomus tieteellistä tutkielmaa toimivampi, vaikkakaan ei niin näkyvä kertomuksen jäsentäjä. Salapoliisikertomuksen tavoin Neuromaani nojaa pitkälti lukijan ja muodon väliseen vuorovaikutukseen, joka pelinä luo romaanin reitit ja tuottaa vaikutelman romaanin ensyklopedisuudesta. Salapoliisikertomuksessa tämä 
peli on yleensä asetettu lukijan ja etsivän keskinäisenä kilpailuna, mutta Neuromaanissa se on luonnoltaan formaalimpi.

Varsinaiset komponentit, joiden pohjalta Neuromaani kuvaa omaa tiedollisen etsimisen prosessiaan, voidaan jakaa muodollisiin ominaisuuksiin ja interaktiivisiin ilmentymiin. Yhtäältä Neuromaanin pelikirjamainen muoto asettuu päätäntöjen runsauden ja sokkelomallisen liikkumavaransa perustalle: fyysisessä kirjassa voi olla vain rajallinen määrä juonilinjoja. Muotoa leimaa myös Näreen harhaisuus ja ajatusleikki lukemisesta kulkuna Näreen aivojen labyrintissa. Toisaalta Neuromaani on selvästikin käyttöliittymä, jossa lukijalle varataan tiedollisen organisoijan asema. Näre on puskurihahmona heikko, eikä Neuromaanin kohdalla voida niinkään puhua etsivästä mallilukijana kuin lukijasta toimijana, joka ideoi ja yhdistelee itselleen vastaavan aseman. Juuri lukija järjestelee valinnoillaan osiot sarjoiksi päästäkseen eteenpäin. Tällä tavoin hän - osin ennalta aavistamattaan, osin silkkaa tiedonjanoaan - tulee toteuttaneeksi sarjoihin sisällytettyjä rikoksia. Näin romaani kääntää selvästi salapoliisikertomuskaavan nurin ja mahdollistaa Foucaultin heiluriakin selvemmin mahdottomana pidetyn: tottelemiskokeessa lukijasta ei tehdä niinkään tarinan sankaria kuin sen todellinen murhaaja.

Muodollisia ja interaktiivisia komponentteja yhdistää toisiinsa rikollisneromaisen neurologijoukon takaa paljastuvan "Neurokoreografin" ideoima käyttöliittymän tiedollinen pohja. Näreen harhaisuus yhdistettynä lukuisiin rikoksia sivuaviin vihjeisiin saa lukijan kiinnostumaan varsinaisen tiedollisen aineksen sijaan Neuromaanin episteemistä sinänsä. Siirryttyään Näreen mieleen lukija alkaa kuin vaistomaisesti etsiä vihjeitä todellisista tapahtumista Näreen harhojen taustalla, pitihän romaanin kertoa rikoksista, joihin neurologit ovat syyllistyneet. Tässä etsiväntyössään hän etsii kiintopisteitä ja luonnostelee lukuohjeita.

Jos Yli-Juonikkaan romaani kompuroisikin hyperbolassaan, on siinä riittävästi myös vastavoimia pitämään romaanin tiedollinen aines koossa. Metafyysisen salapoliisikertomuksen näkökulmasta hyvä kysymys tosin on, missä märin tämä tasapaino voi muuttaa lukemisen konventioita; miten paljolti lukija voi lopulta osallistua kirjallisen ensyklopedian luomiseen.

\section{Viitteet}

1 "Ensyklopedinen kertomus" (Mendelson 1976) ja "ensyklopedinen romaani” (Burn 2007) käsitetään tässä artikkelissa pitkälti synonyymeina ja täsmällisempinä käsitteinä kuin ”systeemiromaani" (LeClair 1996), "megaromaani" (Karl 2001, 155-225) ja "maksimalistinen romaani" (Ercolino 2014). Rajaan käsitteen tietoisesti sotienjälkeiseen aikaan: muun muassa Burn (2007) ja Ercolino (2014) esittävät ensyklopedisen romaanin genren syntyvän vasta Pynchonin ja William Gaddisin myötä, olkoonkin että kirjallisuudenhistoria tuntee monia, varhaisempien aikakausien ensyklopedisia kertomuksia. Vaikka ensyklopedisuuden määre liitetään tavallisesti laajaan romaaniin, on se mahdollinen myös novellimuodon kohdalla, 
jolloin tiedollisen kokonaiskuvan sijaan merkitsevämpää on tiedonjäsennyksen metodologia kokonaiskuvan mahdollisuutena (Kuusisto 2013, 43).

${ }^{2}$ Stefano Ercolino (2014, 114-118) nimeää tämän kaksijakoisuuden kaaos- ja kosmosfunktion dialektiikaksi, siinä missä Frederick R. Karl $(2001,162)$ kokoaa kysymyksen paradoksin alle: ensyklopedinen romaani on samanaikaisesti laaja ja suljettu, kaoottinen ja juonellisesti koherentti, kokeellinen ja kuitenkin monilta osin konventionaalinen.

${ }^{3}$ Lisää metafyysisen salapoliisikertomuksen genealogiasta, ks. Merivale \& Sweeney 1999, 18. Pääpiirteissään genren tutkimus on painottunut minimalistiseen haaraan, kun taas "tavoiltaan karnevalistiset, tyyliltään maksimalistiset ja rakenteeltaan keskeispakoiset" romaanit (mt., 19; suom. V.K.) ovat jääneet vähemmälle huomiolle nimenomaan metafyysisinä salapoliisikertomuksina. Jos minimalistisessa haarassa painottuvat rikostutkinnan päätännöttömyys, labyrinttikaavat ja kirjalliset leikit, laajenee maksimalistinen haara myös kohti muita medioita, tiedollisia kokonaisuuksia ja yhteiskuntaa.

${ }^{4}$ Moni lukija tunnistaa Riekkisen ja Rinteen petossyytteet myös historiallisesti tosiksi.

\section{Kirjallisuus}

Brander, Juhani 2012. Aivojeni metelissä uusi todellisuus. Turun Sanomat 13.2.2012.

Brownson, Charles 2014. The Figure of the Detective. A Literary History and Analysis. Jefferson: McFarland.

Burn, Stephen J. 2007. The Collapse of Everything. William Gaddis and the Encyclopedic Novel. Joseph Tabbi and Rone Shavers (ed.), Paper Empire. William Gaddis and the World System. Tuscaloosa: The University of Alabama Press, 46-62.

Clark, Hilary 1990. The Fictional Encyclopedia. Joyce, Pound, Sollers. New York: Routledge.

Eco, Umberto 1986. Semiotics and the Philosophy of Language. Bloomington: Indiana University Press.

Eco, Umberto 1994. Six Walks in the Fictional Woods. Cambridge: Harvard University Press.

Ercolino, Stefano 2014. The Maximalist Novel. From Thomas Pynchon's Gravity's Rainbow to Roberto Bolaño's 2666. Trans. Albert Sbragia. New York: Bloomsbury.

Juntunen, Tuomas 2012. Labyrintin vankina? Parnasso 6-7/2012, 92-93.

Karl, Frederick R. 2001. American Fictions 1980-2000. Whose America Is It Anyway? Bloomington: XLibris.

Kursula, Sakari 2013. Tekstikoneen aivotoiminta. Ergodisuus ja sen mallintaminen Jaakko Yli-Juonikkaan romaanissa Neuromaani. Kirjallisuuden pro gradu -tutkielma. Jyväskylän yliopisto. https://jyx.jyu.fi/dspace/handle/123456789/42818 (26.2.2016).

Kuusisto, Pekka 2013. Ensyklopedian aatehistoriasta ja ensyklopedisesta novellista Poella, Kafkalla ja Borgesilla. Synteesi 4/2013, 27-51. 
LeClair, Tom 1996. The Prodigious Fiction of Richard Powers, William Vollmann, and David Foster Wallace. Critique 38(1), 12-37.

Mendelson, Edward 1976. Encyclopedic Narrative. From Dante to Pynchon. MLN 91(6), 1267-1275.

Merivale, Patricia \& Susan Elizabeth Sweeney 1999. The Game's Afoot. On the Trail of the Metaphysical Detective Story. Patricia Merivale \& Susan Elizabeth Sweeney (eds.), Detecting Texts. The Metaphysical Detective Story from Poe to Postmodernism. Philadelphia: University of Philadelphia Press, 1-24.

Mäkelä, Matti 2012. Materiaalivarastosta löytyy herkkujakin. Helsingin Sanomat 17.9.2012.

Pyrhönen, Heta 1999. Mayhem and Murder. Narrative and Moral Problems in the Detective Story. Toronto: University of Toronto Press.

Tani, Stefano 1984. The Doomed Detective. The Contribution of the Detective Novel to Postmodern Italian and American Fiction. Carbondale: Southern Illinois University Press.

Yli-Juonikas, Jaakko 2012. Neuromaani (= N). Helsinki: Otava. 